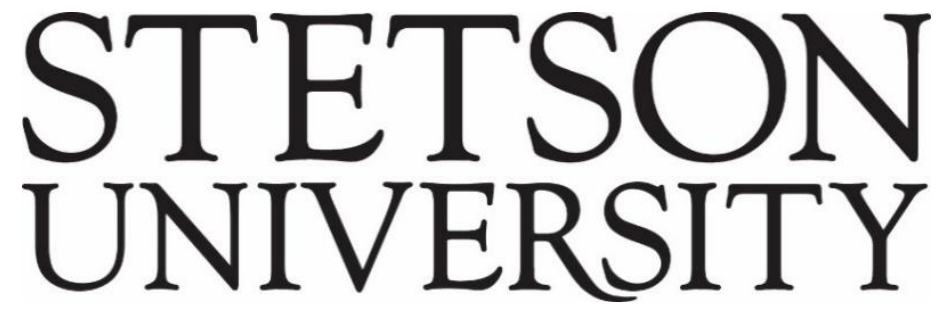

Voices of Reform: Educational Research to Inform and Reform

Volume 1 - Issue $1 \bullet$ Editor Statement

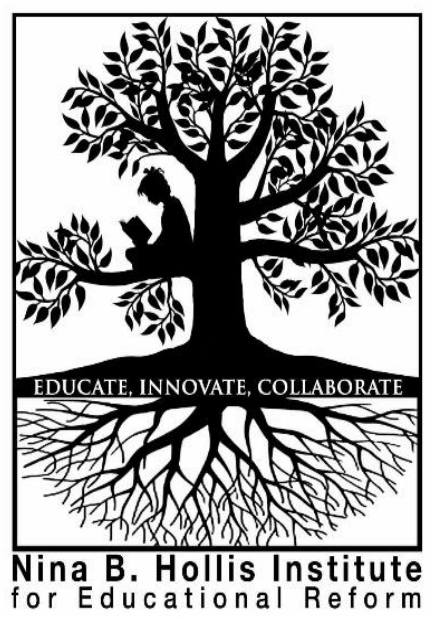

September 2018

Voices of Reform: Inaugural Editor Statement

Lou L. Sabina

Stetson University

Follow this and additional works at: http://www.voicesofreform.com

Recommended Citation

Sabina. L. L. (2018). Voices of reform: Inaugural editor statement. Voices of Reform, 1(1), 2-4. Retrieved from https://www.voicesofreform.com/article/4458-editor-statement-volume-1-issue-1. doi:10.32623/1.00002

http://dx.doi.org/10.32623/1.00002

Revisions

Publication date: September $15^{\text {th }}, 2018$ 


\title{
Voices of Reform: Inaugural Editor Statement
}

\author{
Lou L. Sabina ${ }^{1}$ \\ ${ }^{1}$ Department of Education \\ Stetson University, United States \\ lsabina@stetson.edu
}

It is my pleasure to welcome you to the inaugural issue of Voices of Reform: Educational Research to Inform and Reform. We are excited to present seven high-quality articles addressing many facets of school reform from scholars, practitioners, and scholar/practitioners across the United States. We are optimistic that our journal will fill a need for scholarship concerning our changing education system.

We would like to acknowledge the continued support from the Hollis Foundation. The Nina B. Hollis Institute for Educational Reform was endowed by Mark and Lynn Hollis in 2000 in memory of Mark's mother-Nina B. Hollis who was an avid reader and supporter of education. The Institute's early work was to develop local incubation projects to test innovative ideas that would positively impact K-12 classrooms, with specific attention to closing the opportunity gap for children in marginalized settings. Through their continued and dedicated support, we have been able to embark on this ambitious endeavor. It is our hope that these and future articles will spark new ideas and give a voice to the under-represented children in our educational system.

We would like to acknowledge several individuals who made this idea a reality. A special thanks goes to our graduate student during the 2017-2018 school year, Saige Liparulo, who significantly helped with the development and conceptual framework for the journal. We also thank our executive committee - Dr. Chris Colwell, Ms. Peggy Fox, Dr. Elizabeth Heins, Dr. Kathy Piechura-Couture, Dr. Leila Roach, Dr. Mercedes Tichenor, and Dr. Debra Touchton, who served as our reviewers for our inaugural issue.

Our first article comes from Dr. Pamela "Sissi" Carroll, Dean of the College of Community Innovation and Education at the University of Central Florida. In her article, Dr. Carroll discusses the transformation of Teacher Preparation Programs in her College to meet the changing demographics across the United States, focusing on the growing need for preparation to urban schools. Dr. Carroll presents a model that may be duplicated and modified as other colleges and universities reform their teacher education programs. 
Next, we travel from Florida to Texas, as Dr. Joshua "JC" Childs, Assistant Professor of Education, presents a policy discussion regarding the new "Districts of Innovation" initiative, a program from the Texas Education Agency to improve low-performing school districts and unburden higherperforming school districts. Dr. Childs addresses the processes and procedures used by various Texas school districts, and also offers a comparative to a similar initiative which took place in Colorado. This article can serve as a reminder for scholars, school leaders, and practitioners of the many different layers that exist when State Departments of Education propose new programs to improve school performance.

Texas's neighbor to the north, Oklahoma, brings us a unique piece on school choice, an issue highly debated in current discussions surrounding school reform. Dr. Katherine A. Curry, program director and Associate Professor of Educational Studies at Oklahoma State University, provides an article discussing how parents can be empowered through school choice. Dr. Curry provides a case study analysis of a P-3 school in a high-poverty environment and how school choice has empowered families in this academy school and increased community involvement.

An examination of teacher recruitment practices in rural school districts is provided by Dr. Susan Curtin, Associate Professor of Educational Leadership at the University of South Dakota. Dr. Curtin discusses the challenges of both recruitment and retention in geographically sparse areas, including limited and inadequate resources, lower pay, and more challenging working conditions.

An additional colleague in the Midwest, Dr. Chad Lochmiller, Assistant Professor of Educational Leadership and Policy Studies at Indiana University - Bloomington, provides an analysis of school district leadership coaching for school principals. Dr. Lochmiller specifically examines the tension that exists when district leaders are responsible for providing professional development and coaching for their building-leaders while remaining responsible for their evaluations.

Our sixth article ventures to the Rust Belt, where University of Pittsburgh Associate Professor of Administration and Policy Studies, Dr. Maureen McClure, pens a provocative, open-ended essay discussing why the time is now for school finance reform. Using the popular "wicked problems" framework commonly found in disaster education, Dr. McClure suggests that more emphasis needs to be placed on proactive finance controls, especially in the era of increasing pensions and required contributions from current school teachers to meet the needs of the retired.

Finally, we return to the West Coast of Florida, for our Voices from the Field article, where Dr. Ronald "Ron" Porter, Director of Service Learning at Eckerd College, discusses a partnership between Eckerd College and Plenitud, an eco-educational organization located in Las Marias, Puerto Rico specializing in permaculture, bio-construction, and sustainable community service projects. This partnership faced a significant challenge this past calendar year in the wake of Hurricane Maria, and Dr. Porter shares the trials and tribulations that his team faced.

We welcome submissions to our journal from scholars, practitioners, and scholar/practitioners as a traditional research article/position piece or a submission to our Voices from the Field section. We guarantee a double-blind peer review with a rapid turnaround, no fees for submission, and quick online posting as soon as your article is approved. If you have any questions regarding a submission, please contact me, Dr. Lou L. Sabina, at lsabina@ stetson.edu. 
As a final note, it is extremely important that we acknowledge the contributions of Margaret "Peggy" Fox to the launch of our first journal. Peggy has been an employee at Stetson University for the last 15 years. Prior to accepting the role of Project Director for the Nina B. Hollis Institute for Education Reform, Peggy completed her M.Ed. in Social Justice Education at Stetson University. We have been extremely fortunate to have Peggy share our passion for educational change for the last two years and we wish her well in her new position as the assistant registrar for University of the South.

We hope you enjoy this first issue of Voices of Reform: Educational Research to Inform and Reform.

Dr. Lou L. Sabina

Editor-in-Chief

Voices of Reform 